\title{
EFEKTIVITAS PEMBELAJARAN KOOPERATIF TIPE THINK PAIR SHARE PADA MATERI MATEMATIKA KELAS VII
}

\author{
Sri Satriani ${ }^{1}$, Randy Saputra Mahmud ${ }^{2)}$, Isnawati ${ }^{3)}$, \\ ${ }^{1)}$ Universitas Muhammadiyah Makassar, Jalan Sultan Alauddin No.259, Makassar; \\ srisatriani@unismuh.ac.id \\ ${ }^{2)}$ Universitas Muhammadiyah Makassar, Jalan Sultan Alauddin No.259, Makassar; \\ randysmahmud@yahoo.co.id \\ ${ }^{3)}$ Universitas Muhammadiyah Makassar, Jalan Sultan Alauddin No.259, Makassar; \\ isnawati@yahoo.com
}

\begin{abstract}
The aims of this study to know the effectiveness of think pair share cooperative model toward the mathematics learning outcomes for students in class VIII ${ }_{B}$ SMPN 3 Sungguminasa. This research was a pre-experimental research, the design was an one group pretest-posttest which involved in one class during 5 meetings. The learning achievement test, student activity observation, and student questionnaire responses were applied for collecting data. The data analyzed by descriptive and inferensial technique. The results showed that the average score of learning outcomes before being taught mathematics learning with the application of think pair share cooperative model was 37.10 with standard deviation 12,169, which showed that completeness classically was not achieved, while the average score the average mathematics learning outcomes of students after being taught mathematics learning with the application of the think pair share cooperative model was 84.17 with standard deviation 67.57 having achieved classical completeness with a normalized gain value of 0.73 being in the high category. Student activities in the active category where the average percentage $82.49 \%$. Student positive responses showed the average percentage was $94.29 \%$. Based on these results it can be concluded that mathematics learning through the application of think pair share cooperative model in class $\mathrm{VII}_{\mathrm{B}}$ SMPN 3 Sungguminasa applied effectively.
\end{abstract}

Keywords: effectiveness, cooperative, think pair share

\begin{abstract}
Abstrak
Penelitian ini bertujuan untuk mengetahui keefektifan hasil pembelajaran matematika melalui penerapan model pembelajaran kooperatif tipe think pair share. Jenis penelitian ini merupakan penelitian pre-eksperimen. Desain pada penelitian ini adalah one group pretest-posttest dengan lama penelitian sebanyak 5 pertemuan. Tes hasil belajar, lembar observasi aktivitas, dan respo peserta didik digunakan untuk mengumpulkan data. Data yang telah dikumpulkan dianalisis secara deskriptif dan inferensial. Hasil penelitian menunjukkan bahwa rata. Hasil penelitian menunjukkan bahwa skor rata-rata hasil belajar matematika peserta didik sebelum diajar dengan pembelajaran matematika melalui penerapan model pembelajaran kooperatif tipe think pair share adalah 37,10 dengan standar deviasi 12,169, yang menunjukkan bahwa tidak tercapai ketuntasan secara klasikal. Sedangkan skor rata-rata hasil belajar matematika peserta didik setelah diajar dengan pembelajaran matematika melalui penerapan model pembelajaran kooperatif tipe think pair share adalah 84,17dengan standar deviasi 67,57 telah tercapai ketuntasan secara klasikal dengan nilai gain ternormalisasi yaitu 0,73 berada pada kategori tinggi. Aktivitas peserta didik berada pada kategori aktif denga persentase $82,49 \%$. Respon peserta didik menunjukkan positif dengan persentase $94,29 \%$. Berdasarkan hasil penelitian tersebut dapat disimpulkan bahwa pembelajaran matematika
\end{abstract}


melalui penerapan model pembelajaran kooperatif tipe think pair share pada peserta didik kelas $\mathrm{VII}_{\mathrm{B}}$ SMP Negeri 3 Sungguminasa efektif diterapkan.

Kata Kunci: efektivitas, kooperatif, think pair share

\section{Pendahuluan}

"Santrock (2013) mengemukakan bahwa pembelajaran dari aspek psikologis didefinisikan sebagai pengaruh permanen atas perilaku, pengetahuan dan keterampilan berpikir yang diperoleh melalui pengalaman". Sehingga suatu pembelajaran dianggap berhasil jika terjadi perubahan permanen perilaku, pengetahuan, dan keterampilan berpikir. "Tiro (2010) mengemukakan bahwa matematika dapat diartikan sebagai sebagai alat dan metode untuk berpikir". Sebagai alat, matematika membantu peserta didik untuk mengembangkan pengetahuan, perilaku dan keterampilan. Sebagai metode berpikir, matematika dapat digunakan sebagai wahana untuk membentuk cara berpikir dan kepribadian peserta didik. Pembelajaran matematika berhasil apabila peserta didik yang tadinya tidak tahu akhirnya menjadi tahu mengenai konsep matematika yang diajarkan serta memiliki perubahan sikap dan keterampilan terhadap apa yang dimilikinya.

Berdasarkan hasil observasi yang dilaksanakan pada kelas $\mathrm{VII}_{\mathrm{B}}$ SMP Negeri 3 Sungguminasa dalam proses pembelajaran matematika ditemukan bahwa hasil belajar matematika peserta didik masih rendah, dimana belum mencapai kriteria ketuntasan minimal yang ditentukan oleh sekolah yakni 75 dan peserta didik kurang berpartisipasi dalam pembelajaran. Hal ini dikarenakan guru masih menggunakan pembelajaran langsung yang strategi mengajarnya lebih banyak diberikan melalui ceramah sehingga suasana belajar peserta didik membosankan. Salah satu tipe pembelajaran kooperatif yang dapat mendorong partisipasi peserta didik dalam kelas, sekaligus meningkatkan hasil belajar peserta didik adalah model pembelajaran kooperatif tipe Think Pair Share (TPS). Berdasarkan hasil penelitian sebelumnya oleh Susanti (2017) bahwa "terdapat pengaruh penggunaan model pembelajaran TPS terhadap hasil belajar IPA siswa kelas VIII ditinjau dari kerja sama siswa". "Jatmiko (2018) mengemukakan bahwa model pembelajaran TPS 
berpengaruh terhadap kognitif dan sikap peserta didik". “Afthina (2017) mengemukakan bahwa TPS dengan menggunakan pendekatan RME dapat meningkatkan keaktifan, pemahaman materi siswa, serta pembelajaran matematika menjadi lebih bermakna". Demikian pula penelitian oleh Zai (2017) "penggunaan TPS dapat meningkatkan penerapan konsep peserta didik pada topik permutasi dan kombinasi". Sehingga berdasarkan penelitian tersebut, melalui model pembelajaran kooperatif tipe TPS yang diterapkan pada penelitian ini, peserta didik dapat mencapai keefektifan pemebelajaran dengan dapat menginterpretasi ide mereka bersama dan memperbaiki pemahaman, serta pembelajaran matematika yang lebih bermakna. Dalam hal ini guru sangat berperan penting untuk membimbing peserta didik melakukan diskusi sehingga tercipta suasana belajar yang aktif, kretif, efektif dan menyenangkan. Tujuan dari penelitian ini adalah untuk mengetahui hasil belajar peserta didik sebelum dan setelah proses pembelajaran matematika melalui penerapan model pembelajaran kooperatif tipe TPS, serta untuk mengetahui aktivitas dan respon peserta didik selama proses pembelajaran kooperatif tipe TPS.

\subsection{Efektivitas}

"Kamus Besar Bahasa Indonesia (2011) Efektivitas berasal dari kata efektif berarti ada efeknya, manjur, mujarab dan mapan". "Yaumi (2013) efektivitas diartikan sebagai "tingkat ketercapaian tujuan yang dapat ditunjukkan dengan membandingkan hasil yang diperoleh dengan hasil yang ditargetkan”. Terkait dengan pembelajaran, keefektifan pembelajaran berarti ketercapaian tujuan pembelajaran untuk memperoleh tindakan yang tepat guna. "Slavin dalam Patta (2013) mengemukakan keefektifan pembelajaran terdiri dari empat indikator, yaitu Quality of Instruction, Appropriate of instruction (Kesesuaian tingkat pembelajaran), Incentive (Insentif), dan Time”. Sehingga indikator efektivitas yang disusun dalam penelitian ini adalah hasil belajar, respon, dan aktivitas peserta didik serta keterlaksanaan pembelajaran. 


\subsection{Pembelajaran Kooperatif}

"Suryanto (2013) mendefinisikan pembelajaran kooperatif merupakan model pembelajaran yang mengutamakan kerja sama antara peserta didik untuk mencapai tujuan pembelajaran". "Sunal dalam Suryanto (2013) pembelajaran kooperatif learning memiliki pendekatan atau serangkaian model yang khusus dirancang untuk memberi dorongan kepada peserta didik agar bekerja sama selama proses pembelajaran". Kondisi yang terjadi dalam pembelajaran kooperatif menurut Petocz (2012) "peer learning is used to describe cooperative learning involving joint projects" yaitu adanya kegiatan diskusi dan saling bertutor sebaya antara peserta didik dalam menyelesaikan suatu tugas. Melalui kegiatan tersebut manfaat yang dapat diperoleh siswa menurut Lafleur (2010) "when students were working with a partner, they had someone else to ask for help rather than asking me, the students also seemed more confident in the work that they were doing and completed it with ease" bahwa ketika peserta didik saling bekerja sama, mereka dapat meminta bantuan tanpa ada perasaan segan sehingga menumbuhkan rasa percaya diri pada apa yang mereka kerjakan. Bagi peserta didik yang membantu teman selama proses diskusi, maka mereka akan mendapatkan manfaat lebih, Topping (2011) "for the tutors, it is learning by teaching" yaitu sebagai sarana belajar sambil mengajar sehingga dapat lebih menguasai materi/konsep yang diberikan oleh guru. Adapun manfaat yang dapat diperoleh guru terhadap siswa yang masih belum memahami materi menurut Duran (2010) "during peer tutoring the reduction in management time, the high level of effective work time and the high percentage of success and feedback leads to high rate of academic learning time" yang berarti bahwa mengefektifkan waktu dalam mengulangi penjelasan materi bagi peserta didik yang belum memahami materi.

Sehingga disimpulkan bahwa model pembelajaran kooperatif adalah suatu model pembelajaran yang membagi peserta didik kedalam kelompok kecil yang heterogen guna meciptakan kerja sama antar peserta didik dalam mencapai tujuan pembelajaran. Adapun langkah - langkah pembelajaran kooperatif dapat dilihat pada tabel 1 berikut. 
Tabel 1. Sintaks Pembelajaran Kooperatif.

\begin{tabular}{|c|c|c|}
\hline $\begin{array}{c}\text { Fase } \\
\text { Ke- }\end{array}$ & Indikator & Aktifitas/Kegiatan Guru \\
\hline 1 & $\begin{array}{l}\text { Menyampaikan } \\
\text { tujuan dan } \\
\text { memotivasi peserta } \\
\text { didik }\end{array}$ & $\begin{array}{l}\text { Guru mengomunikasikan semua tujuan pelajaran } \\
\text { yang ingin dicapai pada pelajaran tersebut dan } \\
\text { memotivasi peserta didik untuk belajar dengan } \\
\text { baik. }\end{array}$ \\
\hline 2 & Menyajikan informasi & $\begin{array}{l}\text { Guru menyampaikan informasi kepada peserta } \\
\text { didik dengan jalan demonstrasi atau lewat bahan } \\
\text { bacaan. }\end{array}$ \\
\hline 3 & $\begin{array}{l}\text { Mengorganisasikan } \\
\text { peserta didik ke } \\
\text { dalam kelompok - } \\
\text { kelompok belajar }\end{array}$ & $\begin{array}{l}\text { Guru menjelaskan kepada peserta didik bagaimana } \\
\text { caranya membentuk kelompok belajar dan } \\
\text { membantu setiap kelompok agar melakukan tugas } \\
\text { secara efisien }\end{array}$ \\
\hline 4 & $\begin{array}{l}\text { Membimbing } \\
\text { kelompok bekerja dan } \\
\text { belajar }\end{array}$ & $\begin{array}{l}\text { Guru membimbing kelompok belajar pada saat } \\
\text { mereka mengerjakan tugas. }\end{array}$ \\
\hline 5 & Evaluasi & $\begin{array}{l}\text { Guru mengevaluasi hasil belajar tentang materi } \\
\text { yang telah dipelajari atau masing - masing } \\
\text { kelompok mempresentasikan hasil kerjanya. }\end{array}$ \\
\hline 6 & $\begin{array}{l}\text { Memberikan } \\
\text { penghargaan }\end{array}$ & $\begin{array}{l}\text { Guru mencari cara untuk menghargai upaya atau } \\
\text { hasil belajar individu maupun kelompok secara } \\
\text { proporsional }\end{array}$ \\
\hline
\end{tabular}

\subsection{Think Pair Share (TPS)}

Think Pair Share (TPS) merupakan jenis pembelajaran kooperatif yang dirancang untuk mempengaruhi pola interaksi peserta didik. Menurut Lestari (2015) "TPS merupakan salah satu tipe pembelajaran kooperatif yang merangsang aktivitas berpikir peserta didik secara berpasangan dan berbagi pengetahuan kepada peserta didik lainnya". "Kurniasih (2017) mendefinisikan model pembelajaran TPS sebagai jenis pembelajaran kooperatif yang dirancang untuk mempengaruhi pola pikir peserta didik". Model pembelajaran TPS pertama kali diperkenalkan oleh Frank Lyman di Univesitas Maryland tahun 1985 yang memiliki prosedur secara ekplisit dapat memberi peserta didik waktu lebih banyak untuk berpikir, menjawab, saling membantu satu sama lain, melalui cara ini diharapkan peserta didik mampu bekerja sama, saling membutuhkan dan saling bergantung pada kelompok - kelompok kecil secara koooperatif dengan sesamanya di Universitas Maryland. Sehingga 
disimpulkan bahwa TPS adalah salah satu tipe model pembelajaran kooperatif yang dirancang untuk mempengaruhi pola pikir dan interaksi peserta didik melalui tahap - tahapannya yaitu berpikir, berpasangan dan berbagi. Langkah-Langkah Pembelajaran dari Model Think Pair Share (TPS) dapat dilihat pada tabel 2 berikut.

Tabel 2. Sintaks Pembelajaran Kooperatif Model TPS.

\begin{tabular}{ll}
\hline Indikator & Aktifitas/Kegiatan Guru \\
\hline Tahap 1 & Guru menjelaskan aturan main dan batasan waktu untuk tiap \\
Pendahuluan & $\begin{array}{l}\text { kegiatan, memotivasi peserta didik terlibat pada aktivitas } \\
\text { pemecahan masalah. }\end{array}$ \\
& $\begin{array}{l}\text { Guru menjelaskan kompetensi yang harus dicapai oleh } \\
\text { peserta didik. }\end{array}$ \\
& $\begin{array}{l}\text { Guru menggali pengetahuan awal peserta didik melalui } \\
\text { kegiatan demonstrasi, pertanyaan/masalah yang dikaitkan } \\
\text { dengan materi. }\end{array}$ \\
Pendahuluan & Guru memberikan Lembar Kerja Peserta didik (LKS) \\
& kepada setiap kelompok. \\
& $\begin{array}{l}\text { Peserta didik mengerjakan LKS tersebut secara kelompok } \\
\text { dalam waktu yang sudah ditentukan. }\end{array}$ \\
& Peserta didik dikelompokkan dengan teman sebangkunya \\
Tahap 3 & Peserta didik berdiskusi dengan pasangannya mengenai \\
Pendahuluan & jawaban tugas yang telah dikerjakan \\
& Satu pasang peserta didik dipanggil secara acak untuk \\
Tahap 4 & berbagi pendapat kepada seluruh peserta didik di kelas \\
Pendahuluan & dengan dipandu oleh guru \\
& Guru membantu peserta didik untuk melakukan refleksi atau \\
Tahap 5 & evaluasi terhadap hasil pemecahan masalah yang telah \\
Pendahuluan & mereka diskusikan, dan Peserta didik dinilai secara individu \\
& dan kelompok. \\
\hline
\end{tabular}

\section{Metodologi Penelitian}

Jenis penelitian adalah Pra-Eksperimen dengan melibatkan satu kelompok yaitu peserta didik kelas VIIB SMP Negeri 3 Sungguminasa, dengan desain penelitian adalah One group Pretest-Posttes yang dapat dilihat pada tabel 3 berikut.

Tabel 3. Statistik Hasil Belajar Peserta didik Sebelum dan Setelah Pembelajaran

\begin{tabular}{ccc}
\hline Pretest & Treatment & Posttest \\
\hline $\mathrm{O}_{1}$ & $\mathrm{X}$ & $\mathrm{O} 2$ \\
\hline
\end{tabular}


Penelitian ini mengambil populasi seluruh peserta didik kelas VII SMP Negeri 3 Sungguminasa sebanyak 11 kelas. Pengambilan sampel dalam penelitian ini menggunakan "Simple Random Sampling". Instrumen Penelitian yang digunakan dalam penelitian ini adalah tes hasil belajar (pretest dan posttest), lembar observasi aktivitas peserta didik dan angket respon peserta didik. Data tes hasil belajar diperoleh melalui pemberian pretest sebelum pembelajaran dan posttest setelah pembelajaran, soal yang diberikan berupa soal essay. Data aktivitas peserta didik diperoleh melalui hasil pengamatan aktivitas peserta didik dalam pembelajaran. Data respon peserta didik diperoleh melalui angket respon yang diberikan kepada peserta didik setelah seluruh pembelajaran selesai.

Data yang telah dikumpulkan dianalisis menggunakan teknik analisis deskriptif dan teknik analisis inferensial. Untuk mengetahui sejauh mana kemajuan hasil belajar peserta didik antara sebelum dan sesudah penggunaan model pembelajaran maka digunakan uji gain pada data pretest dan posttest. Keberhasilan aktivitas peserta didik dalam penelitian ini apabila minimal 75\% dari seluruh komponen pada lembar observasi aktivitas peserta didik memenuhi kriteria aktif. Adapun data respon peserta didik dianalisis dengan mencari presentase jawaban peserta didik untuk tiap-tiap pertanyaan dalam angket respon peserta didik dianalisis dengan melihat persentase dari respon peserta didik. Sebelum mengadakan uji statistik inferensial yaitu dengan menggunakan statistik Uji-t, maka terlebih dahulu dilakukan uji syarat.

\section{Hasil dan Pembahasan}

Hasil analisis statistika deskriptif menunjukkan distribusi skor hasil belajar sebelum dan sesudah pembelajaran dengan melalui penerapan model pembelajaran kooperatif tipe TPS yang dapat dilihat pada tabel 4 berikut.

Tabel 4. Statistik Hasil Belajar Peserta didik Sebelum dan Setelah Pembelajaran

\begin{tabular}{lll}
\hline Statistik & Sebelum Pembelajaran & Setelah Pembelajaran \\
\hline Ukuran Sampel & 30 & 30
\end{tabular}




$\begin{array}{lll}\text { Skor Ideal } & 100 & 100 \\ \text { Skor Maksimum } & 60 & 98 \\ \text { Skor Minimum } & 20 & 75 \\ \text { Rentang Skor } & 40 & 23 \\ \text { Mean } & 37,10 & 83,50 \\ \text { Median } & 38,00 & 83,50 \\ \text { Modus } & 20 & 77 \\ \text { Standar Deviasi } & 12,169 & 67,57 \\ \text { Variansi } & 148,093 & 45,385\end{array}$

Berdasarkan Tabel 4 terlihat bahwa skor rata-rata hasil belajar matematika sebelum diberikan perlakuan sebanyak 30 peserta didik sebesar 37,10 dengan standar deviasi 12,169 dari skor ideal 100 berada pada kategori sangat rendah berdasarkan kategori skor hasil belajar peserta didik. Sedangkan hasil belajar peserta didik setelah diberikan perlakuan diperoleh skor rata-rata hasil belajar peserta didik sebesar 84,17 berada pada katetori tinggi. Persentase aktivitas peserta didik yang diharapkan meningkat setiap pertemuan dalam pelaksanaan pembelajaran matematika melalui penerapan model pembelajaran kooperatif tipe TPS matematika melalui penerapan model pembelajaran kooperatif tipe TPS yaitu sebesar $82,49 \%$. Rata-rata presentase respon peserta didik yang diharapkan meningkat setiap pertemuan dalam pelaksanaa pembelajaran matematika melalui penerapan model pembelajaran kooperatif tipe TPS matematika melalui penerapan model pembelajaran kooperatif tipe TPS yaitu 94,29\%.

Analisis statistik inferensial pada bagian ini digunakan untuk pengujian hipotesis yang telah dirumuskan dan sebelum melakukan analisis statistik inferesial Uji-t, maka terlebih dahulu dilakukan uji normalitas Kolmogorov-smirnov dan uji gain dengan menggunakan bantuan program SPSS. Hasil analisis skor rata-rata untuk pretest menunjukkan nilai Pvalue $>\alpha$ yaitu $0,885>0,05$ skor rata-rata posttest untuk menunjukkan nilai Pvalue $>\alpha$ yaitu 0,674>0,05.Hal ini menunjukkan bahwa ada perbedaan skor pretest dengan skor posttest berdistribusi normal. Berdasarkan hasil analisis SPSS versi 16 tampak bahwa nilai sig. (2-Tailed) = $0,000<0,005$ menunjukkan bahwa rata-rat hasil belajar peserta didik setelah diajar melalui penerapan model pembelajaran kooperatif tipe TPS lebih dari 75. Bahwa 
H0 ditolak dan H1 diterima yakni rata-rata hasil belajar posttest peserta didik yang berarti bahwa terjadi peningkatan hasil belajar matematika peserta didik kelas VIIB SMP Negeri 3 Sungguminasa lebih dari atau sama dengan KKM yaitu 75. Penguji ketuntasan klasikal peserta didik dilakukan dengan menggunakan uji proporsi. Untuk uji proporsi dengan menggunakan taraf signifikan $\alpha 5 \%$ diperoleh $\mathrm{Z}$ tabel $=$ 1,64 berarti $\mathrm{H} 0$ diterima jika $\mathrm{Z}$ hitung $\leq 1,64$. Karena diperoleh nilai $\mathrm{Z}$ hitung 2,87 maka H0 ditolak dan H1 diterima artinya proporsi peserta didik mencapai kriteria ketuntasa $75=80 \%$ dari keseluruhan peserta didik yang mengikuti tes. Dari analisis diatas dapat disimpulkan bahwa skor rata-rata hasil belajar peserta didik setelah pembelajaran matematika melalui penerapan model pembelajaran kooperatif tipe TPS telah memenuhi kriteria keefektifan.

Dari hasil penelitian diketahui bahwa terjadi peningkatan hasil belajar matematika peserta didik setelah menggunakan model pembelajaran TPS. Menurut (Kurniasih, 2017), "mendefinisikan model pembelajaran Think Pair Share (TPS) atau berpikir berpasangan berbagi adalah jenis pembelajaran kooperatif yang dirancang untuk mempengaruhi pola pikir peserta didik". Adapun menurut (Shoimin, 2014), "Think Pair Share (TPS) adalah suatu model pembelajaran kooperatif yang memberi peserta didik waktu untuk berpikir dan merespon serta saling bantu satu sama lain. Model ini memperkenalkan ide "waktu berpikir atau waktu tunggu" yang menjadi faktor kuat dalam meningkatkan kemampuan peserta didik dalam merespon pertanyaan. Pembelajaran kooperatif model Think Pair Share ini relatif lebih sederhana karena tidak menyita waktu yang lama untuk mengatur tempat duduk ataupun mengelompokkan peserta didik dan pembelajaran ini melatih peserta didik untuk berani berpendapat dan menghargai pendapat teman", Sehingga dapat meningkatkan hasil belajar peserta didik. Hal ini dapat dilihat pada rata-rata hasil belajar matematika sebelum diberikan pretest $=37,10$ dengan standar deviasi 12,169 dan rata-rata setelah diberikan posttest $=84,17$ dengan standar deviasi $=$ 67,57. Peningkatan belajar matematika memberikan hasil yang signifikan. 
Penggunaan model pembelajaran TPS efektif terhadap peningkatan hasil belajar peserta didik dalam mata pelajaran matematika kelas VIIB SMP Negeri 3 Sungguminasa. Menurut (Kurniasih, 2017), ” TPS merupakan salah satu tipe pembelajaran kooperatif dikembangkan oleh Frank Lyman Univesitas Maryland tahun 1985. Think Pair Share memiliki prosedur yang secara ekplisit dapat memberi peserta didik waktu lebih banyak untuk berpikir, menjawab, saling membantu satu sama lain. Melalui cara seperti ini diharapkan peserta didik mampu bekerja sama, saling membutuhkan dan saling bergantung pada kelompok kelompok kecil secara koooperatif. Hasil belajar peserta didik dalam mata pelajaran matematika dengan model pembelajaran Kooperatif Tipe TPS efektif diterapkan.

Keefektifan aktifitas peserta didik selama proses pembelajaran matematika dapat dilihat pada perolehan rata-rata persentase aktivitas peserta didik yaitu sebanyak $82,49 \%$ aktif dalam pembelajaran matematika. Kriteria keberhasilan aktivitas peserta didik dalam penelitian ini dikatakan efektif apaila minimal $75 \%$ peserta didik terlibat aktif dalam proses pemelajaran. Dengan demikian penerapan model pembelajaran kooperatif tipe TPS dapat meningkatkan aktivitas peserta didik dalam pembelajaran matematika.

Adapun data respon peserta didik menyatakan bahwa bahwa para peserta didik yang memiliki respon positif terhadap kegiatan pembelajaran adalah $75 \%$ dari mereka yang memberi respon positif dari jumlah aspek yang ditanyakan. Respon positif peserta didik terhadap pembelajaran dikatakan tercapai apabila kriteria respon positif peserta didik untuk kegiatan pembelajaran terpenuhi. Berdasarkan jawaban peserta didik dari angket yang dibagikan diperoleh data bahwa 94,329\% peserta didik SMP Negeri 3 Sungguminasa memberikan respon positif dari sejumlah pertanyaan yang diajukan, berarti kriteria respon positif untuk kegiatan pembelajaran terpenuhi. Berdasarkan hasil penelitian bahwa hasil belajar, aktivitas peserta didik dan respon peserta didik terpenuhi.

Hasil analisis statistik inferensial menunjukkan bahwa skor rata-rata hasil belajar peserta didik setelah pembelajaran matematika melalui penerapan model pembelajaran kooperatif tipe TPS tampak nilai p (sig.(2-tailed)) adalah 0,000 
$<0,005$ lebih dari 75 yang artinya $\mathrm{H}_{0}$ ditolak dan $\mathrm{H}_{1}$ diterima. Hasil analisis inferensial juga mnunjukkan bahwa rata-rata gain termonalisasi tampak bahwa $\mathrm{p}$ (sig.(2-tailed)) adalah $0,000<0,005$ menunjukkan bahwa rata-rata gain termonalisasi pada peserta didik kelas $\mathrm{VII}_{\mathrm{B}}$ SMP Negeri 3 Sungguminasa lebih dari 0,29. Ini berarti bahwa $\mathrm{H}_{0}$ ditolak dan $\mathrm{H}_{1}$ diterima yakni gain termonalisasi hasil belajar peserta didik berada pada kategori sedang. Menunjukkan ketuntasan klasikal untuk uji proporsi dengan menggunakan taraf signifikan $5 \%$ diperoleh $\mathrm{Z}$ tabel $=$ 1,64 berarti $\mathrm{H}_{0}$ diterima jika $\mathrm{Z}$ hitung $\leqslant 1,64$. Karena diperoleh nilai $\mathrm{Z}$ hitung 2,87 maka $\mathrm{H}_{0}$ ditolak dan $\mathrm{H}_{0}$ diterima artinya proporsi peserta didik mencapai kriteria ketuntasan klasikal $80 \%$ dari keseluruhan peserta didik yang mengikuti tes. Ketuntasan belajar peserta didik setelah diajar melalui penerapan model pembelajaran kooperatif tipe TPS secara klasikal lebih dari $80 \%$.

Jadi dapat disimpulkan bahwa secara inferensial hasil belajar matematika peserta didik setelah diajarkan melalui penerapan model pembelajaran kooperatif tipe Think Pair Share (TPS) memenuhi kriteria keefektifan.

\section{Kesimpulan dan Saran}

Pembelajaran matematika melalui penerapan model pembelajaran kooperatif tipe TPS secara deskriptif efektif pada peserta didik kelas VIIB SMP Negeri 3 Sungguminasa ditinjau dari hasil belajar, aktivitas, dan respon peserta didik. Sedangkan secara inferensial terjadi peningkatan hasil belajar matematika pada peserta didik setelah diberikan pembelajaran matematika melalui penerapan model pembelajaran kooperatif tipe TPS. Sehingga disarankan kepada pendidik untuk menjadikan model pembelajaran kooperatif tipe TPS sebagai salah satu alternatif dalam memaksimalkan hasil pembelajaran.

\section{Pustaka}

Afthina, A., Mardiyana, \& Pramudya I., 2017. "Think pair share using realistic mathematic education approach in geometry learning", in International 

Vol. 7 No. 2 Juli 2019 Hal 51 - 64

Conference on Mathematic and Science Education (ICMScE), Journal of Physics, pp 1-6.

Duran, D. 2010. Cooperative interactions in peer tutoring (patterns and sequences in paired writing), Universitat Autonoma de Barcelona, middle gades research journal, 5(1).

Jatmiko, A., Kartina, Y., Irwandani, dkk. 2018. Reading concept map-think pair share (remap-TPS) learning model on cognitive ability and scientific attitude, Jurnal Keguruan dan Ilmu Tarbiyah, 3(2) : 183-195.

Kurniasih, Imas dan Berlin S. 2017. Ragam Pengembangan Model Pembelajaran Untuk Meningkatkan Profesionalitas Guru. Jakarta : Kata Pena.

Lafleur, P.,\& Bluffs, C. 2010. Peer tutoring (student achievement, confidence and the teacher's role). Action Research Project Report, University of NebraskaLincoln, Department of Mathematics.

Lestari, K.E., dan Yudhanegara, M.R. 2015. Penelitian Pendidikan Matematika (Panduan Praktis Menyusun Skripsi, Tesis, dan Karya Ilmiah dengan Pendekatan Kuantitatif, Kualitatif, Kombinasi Disertai dengan Model Pembelajaran dan Kemampuan matematis). Bandung : PT. Refika Aditama.

Patta, R. 2013. Efektivitas Penerapan Pembelajaran Kooperatif Tipe Two Stay Two Stray dan Tipe Jigsaw pada Materi Bangun Datar Siswa Kelas VII SMP (Tesis tidak dipublikasikan). Makassar : Universitas Negeri Makassar.

Petocz, P., Duke, M., Bilgin, A., \& Reid, A. 2012. Exploring peer learning (Student to Student, Lecturer to Lecturer) Asian Social Science, Macquire University, Canadian Center of Science and Education, 8(14).

Santrock, J.W. 2013. Psikologi Pendidikan. Jakarta: Fajar Interpratama Mandiri.

Suryanto, dkk. 2013. Menjadi Guru Profesional (Strategi Meningkatkan Kualifikasi dan Kualitas Guru di Era Global). Jakarta: Erlangga.

Susanti, A., dan Wijayanti, A. 2017. Think pair share (hasil belajar IPA dan kerja sama siswa), Jurnal Pijar MIPA, 12(2) : 51-57.

Tiro, M.A. 2010. Cara Efektif Belajar Matematika, Makassar: Andira Publisher.

Yaumi, M. 2013. Prinsip-Prinsip Desain Pembelajaran Disesuaikan dengan Kurikulum 2013. Jakarta: Kencana. 
Zai, H.P.B., Dwikristanto, Y.P., Yohansa, M. 2017. The use of think-pair-share method to improve grade xii students' capabilities in applying concept of permutation and combination at YSKI Senior High School Semarang, Journal of Holistic Mathematic Education, 1(1) : 41-52. 


\section{BIODATA PENULIS}

\begin{tabular}{|c|c|c|c|}
\hline $\mathbf{A}$ & \multicolumn{3}{|l|}{ IDENTITAS PRIBADI } \\
\hline 1 & Nama Lengkap (beserta gelar) & \multicolumn{2}{|l|}{ Sri Satriani, S.Pd., M.Pd. } \\
\hline 2 & Tempat Tanggal Lahir & \multicolumn{2}{|l|}{ Bulukumba, 01 Oktober 1986} \\
\hline 3 & Email & \multicolumn{2}{|l|}{ srisatriani@unismuh.ac.id } \\
\hline 4 & No HP & \multicolumn{2}{|l|}{085255606813} \\
\hline $\mathbf{B}$ & \multicolumn{3}{|l|}{ IDENTITAS PROFESI } \\
\hline 1 & NIP & \multicolumn{2}{|l|}{63150501} \\
\hline 2 & NIDN/NIDK/NUPTK & \multicolumn{2}{|l|}{0901108602} \\
\hline 3 & Asal Instansi & \multicolumn{2}{|l|}{ Universitas Muhammadiyah Makassar } \\
\hline 4 & Alamat Instansi & \multicolumn{2}{|l|}{ Jl. Sultan Alauddin No. 259, Makassar, 90221} \\
\hline 5 & Kab/Kota & \multicolumn{2}{|l|}{ Makassar } \\
\hline 6 & Provinsi & \multicolumn{2}{|l|}{ Sulawesi Selatan } \\
\hline 7 & No Telp Instansi & \multicolumn{2}{|l|}{$(0411) 866972$} \\
\hline 8 & Lama mengajar & \multicolumn{2}{|l|}{4 tahun $(2015-2019)$} \\
\hline \multirow[t]{7}{*}{9} & \multicolumn{3}{|c|}{ Pengalaman Seminar/Konferensi/Pertemuan Ilmiah } \\
\hline & \multicolumn{2}{|l|}{ Kegiatan } & Sebagai \\
\hline & \multicolumn{2}{|c|}{$\begin{array}{l}\text { 1. Pelatihan Applied Approach (AA) oleh P4M Unismuh Makassar tanggal 15-18 } \\
\text { Maret } 2016\end{array}$} & Peserta \\
\hline & \multicolumn{2}{|c|}{$\begin{array}{l}\text { 2. Seminar Internasional (Prisma 2016) oleh HMJ Matematika Unismuh Makassar } \\
\text { tanggal } 22 \text { Februari } 2016\end{array}$} & Peserta \\
\hline & \multicolumn{2}{|c|}{$\begin{array}{l}\text { 3. Intersection '17 (international seminar on mathematic education 2017) oleh } \\
\text { HMJ pendidikan Matematika Unismuh Makassar tanggal } 6 \text { Mei } 2017\end{array}$} & Peserta \\
\hline & \multicolumn{2}{|c|}{$\begin{array}{l}\text { 4. Workshop Pengembangan SPADA } 2018 \text { oleh FKIP Unismuh Makassar tanggal } \\
\text { 21-31 Maret } 2018\end{array}$} & Peserta \\
\hline & \multicolumn{2}{|c|}{ 5. Sarasehan Pendidikan oleh IKA FKIP Unismuh Makassar tanggal 14 Mei 2018} & Peserta \\
\hline \multirow[t]{7}{*}{10} & \multicolumn{3}{|c|}{ Publikasi Ilmiah } \\
\hline & \multicolumn{2}{|l|}{ Judul } & Tahun \\
\hline & \multicolumn{2}{|c|}{$\begin{array}{l}\text { 1. Eksplorasi Pembelajaran Matematika Berbasis Budaya Lokal Ammatoa Di } \\
\text { Kelas V SDN } 351 \text { Kawasan Adat Ammatoa Kecamatan Kajang Kabupaten } \\
\text { Bulukumba, Jurnal Harmoni, Vol.5 No.1, Januari 2015, ISSN: 2087-9865 }\end{array}$} & 2015 \\
\hline & \multicolumn{2}{|c|}{$\begin{array}{l}\text { 2. Upaya Meningkatkan Hasil Belajar Matematika Melaui Pendekatan } \\
\text { Pembelajaran Kontekstual berlatar Kooperatif pada Siswa Kelas VIII, Jurnal } \\
\text { Sigma, Vol. } 8 \text { Edisi .2 Desember 2016, ISSN : 2085-3610 }\end{array}$} & 2016 \\
\hline & \multicolumn{2}{|c|}{$\begin{array}{l}\text { 3. Pengembangan Diversivikasi Olahan Buah Di Desa Bontobangun Menuju } \\
\text { Kampung Agro Industri, Jurnal Pengabdian Masyarakat, Vol.1 No.2 Juli } 2017\end{array}$} & 2017 \\
\hline & \multicolumn{2}{|c|}{$\begin{array}{l}\text { 4. Komparasi Hasil Belajar Matematika Siswa Kelas X Melalui Penerapan Model } \\
\text { Kooperatif Tipe Number Head Together(NHT) dan Tipe Think Pair Share } \\
\text { (TPS), Jurnal Panrita, Vol. 12. No. } 3 \text { Desember } 2017 \text { ISSN : 1907-6886 }\end{array}$} & 2017 \\
\hline & \multicolumn{2}{|c|}{$\begin{array}{l}\text { 5. PerbandinganHasil Belajar Matematika Menggunakan Model Kooperatif Tipe } \\
\text { Think Pair Check dan Tipe Think Pair Share Pada Kelas VIII SMP, Jurnal } \\
\text { Nabla Dewantara, Vol.3 ,No.1 Mei } 2018 \text { ISSN:2528-3901 }\end{array}$} & 2018 \\
\hline $\mathbf{C}$ & \multicolumn{3}{|c|}{ IDENTITAS MAKALAH } \\
\hline 1 & Judul & \multicolumn{2}{|c|}{$\begin{array}{l}\text { Efektivitas Pembelajaran Kooperatif Tipe Think Pair Share } \\
\text { pada Materi Matematika Kelas VII }\end{array}$} \\
\hline 2 & Penulis & Sri Satriani, S.Pd., M.Pd. & \\
\hline
\end{tabular}

